\title{
10 \\ Marine Resource Use in Transition: Modern Fishing in Tonga, Western Polynesia
}

\author{
Kazuhiro Suda, Faculty of Humanities, Hokkai-Gakuen University
}

\section{Introduction}

Marine resources were very important as a protein source for the initial settlers of the islands of Oceania, where terrestrial animals were extremely scarce. The traditional subsistence of the area consisted of the horticulture of aroid tubers and bananas, arboriculture of breadfruit and coconut trees, and the intensive utilisation of marine resources. Islanders throughout Oceania were prominent horticulturists and fishermen. Anthropological and archaeological studies of fishing in Oceania have mainly focused on the classification and distribution of traditional fishing equipment, as well as the reconstruction of traditional fishing methods and resource use (Bellwood 1978; Lieber 1994; Oliver 1989; Reinman 1967). These studies elucidate the islanders' wealth of knowledge about the ecology of marine animals in order to efficiently exploit them.

After the intrusion of Europeans into this area, however, subsistence activities changed. Especially after the latter half of the 20th century, imported foods such as tinned fish and corned beef have become more important as protein sources. Furthermore, as globalisation of the economy permeates this area, commercial fishing is increasingly taking the place of subsistence fishing. In accordance with the changing socio-economic circumstances of this area, the role of marine resources has grown more varied. While marine resources are still important, the system of resource utilisation and the distribution of catches have drastically changed. The reciprocal exchange systems for fish catches have been disappearing. Instead, people in some islands often sell their catches to their communities. As commercial fishing has become more important, the problem of resource management has become more prevalent.

Taking these issues into account, I discuss the existing problem of contemporary marine resource use by focusing on the case of Ha'ano Island in the Kingdom of Tonga. On Ha'ano Island, subsistence fishing is still the main activity for acquiring animal protein, although outboard motorboats and modern fishing gear, such as nylon nets and lines, have been introduced. In order to elucidate the condition of the transformation of subsistence activities, I will describe the fishing activities in Ha'ano village based on direct observations and by measuring the weight of catches. Furthermore, I will discuss the variation in the choices of fishing activities amongst households in this paper. 


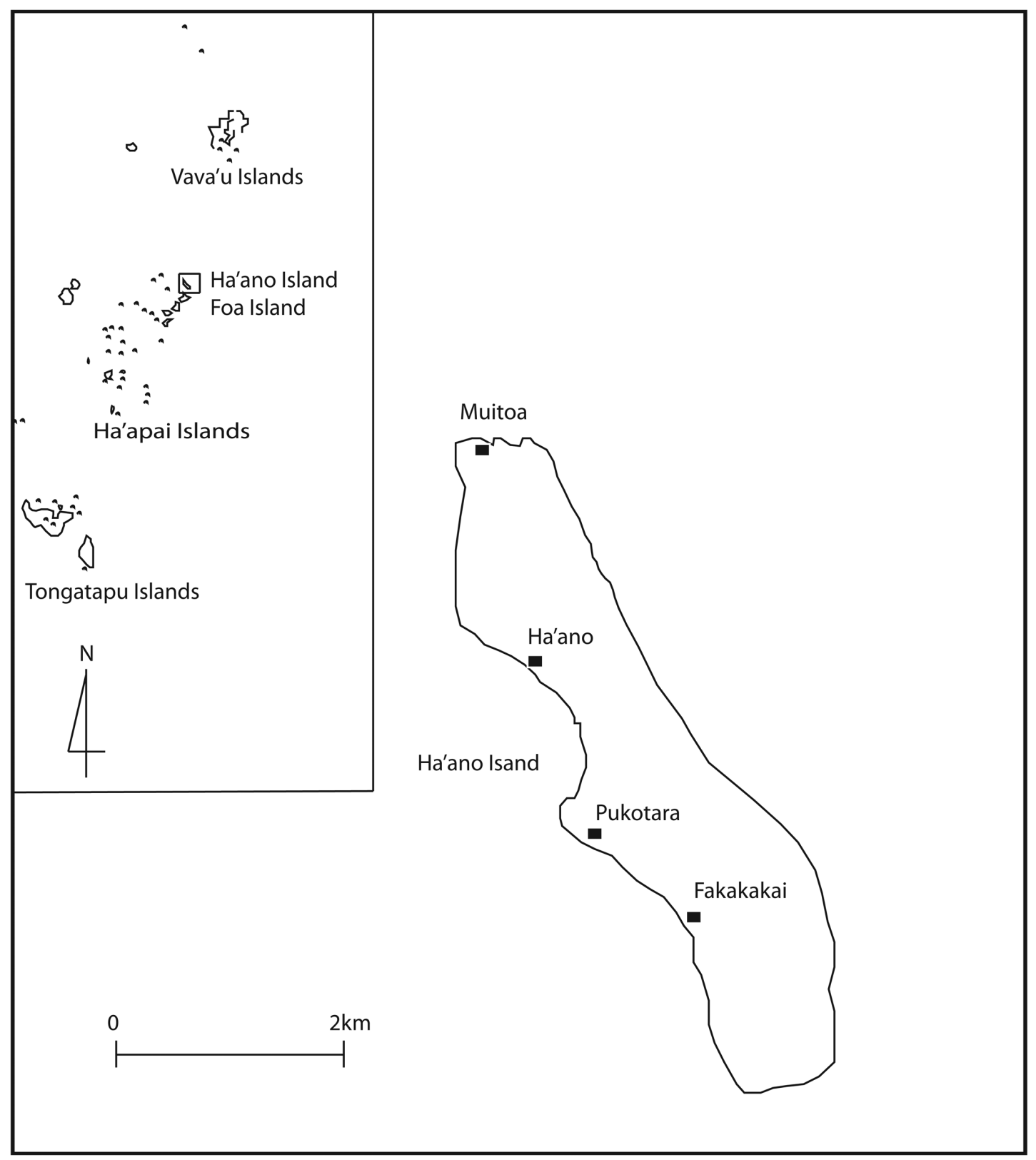

Figure 1. Ha'ano Island in Ha'apai Group of the Tongan Archipelago.

Source: Map by the author.

\section{Ha'ano Village}

Ha'ano Island is situated in the northern part of the Ha'apai Group of the Tongan Archipelago (Figure 1). The administrative capital village of the Ha'apai group is Pangai on Lifka Island, where administrative branches, business offices, middle and high schools, and the market are concentrated. It takes 45 minutes by outboard motorboat, as well as a half hour driving by trucktype buses to travel between $\mathrm{Ha}^{\prime}$ ano Island and Pangai. There are four villages on $\mathrm{Ha}$ 'ano Island: Muitoa, Ha'ano, Pukotara and Fakakakai, from north to south respectively. Although they have primary schools in Ha'ano and Fakakakai, they send their children to Pangai, Nuku'alofa (Tonga's capital), or New Zealand to receive secondary and higher education. 
At the time of our fieldwork from 2001 to 2003, there was no wharf for big ships, no equipment for a water supply, and a small power generator to supply electricity was not installed until 2003. The only means of land transportation on the island was on foot, by bicycle, or in carriages. The insufficiency of infrastructure, furthermore, had confined the economic activities of the island: while some villagers ran the small shop (falekoloa) to sell necessities such as canned goods or soaps, for example, the range of items available was poor and items were sometimes out of stock altogether. Therefore, people often visited Pangai to buy daily living necessities, such as food and clothing.

The population of Ha'ano Village has decreased from over 300 in the early 1970s to under 100 by the year 2000 as a result of emigration to Pangai and Nuku'alofa, or to New Zealand and the United States in order to look for job opportunities (Evans 2001). The remittances from emigrant family members are the main source of income for villagers.

Our research was conducted during two visits, in October of 2001 (11 days) and in October of 2002 (19 days), in Ha'ano Village. The population of Ha'ano Village during our stay was 45 males and 43 females; the number of households was 22 during the research periods. Their subsistence activities consisted of the horticulture of taro (Colocasia esculenta and Xanthosoma sagitifblium) and banana (Musa sp.), arboriculture of breadfruit (Artocarpus altilis) and coconut (Cocos nucifera), fishing, and the raising of pigs and chickens. While the total arable land of the village was 92 acres ( 4.18 acres per household), only 34 acres (1.55 acre per household) were actually used by the villagers for subsistence food production at the time of our research. As each household planted a few breadfruit trees in their homestead, their fruits were consumed as staple foods between April and June, and between September and November. Although villagers raised livestock, such as pigs and chickens, they ate them only a few times a year, especially for communal eating ceremonies related to church activities. The main source of protein intake, therefore, came from marine resources.

While the above mentioned activities by men were for individual consumption, pandanus mats made by women provided a second important source of income to supplement the remittances from the emigrated family members. The mats were important exchange items in marriages and funerals, especially within the Tongan immigrant community in New Zealand.

\section{Fishing Activities}

The deep ocean around Ha'ano Island is a good fishing ground for migratory fish, such as bonito, tuna and dolphinfish, while the shallows near shore provide a suitable environment for bottom fish, such as grouper and parrotfish, and for crustaceans, such as lobster and slipper lobster. As wind and waves are habitually high in the northeast area, fishing activities are mainly conducted in the southwest area; since there are no traditional divisions in the sea among the four villages, every fisherman could freely fish around the island.

Following the restrictive customary rules regarding the division of labour for fishing activities in Tonga, on the other hand, women's fishing activities are limited to gathering certain kinds of shellfish and small octopi from the shoals in front of the village. Unlike Muitoa, the nearest village, there was no shoal in Ha'ano, and women seldom engaged in fishing. Only men engaged in the four fishing activities mentioned below. Out of twenty-two households, eleven engaged in line-fishing, four in diving and harpooning, four in encircling fish with gill nets, and two in the use of stationary nets (Table 1). Only three households engaged in more than one of these activities. 
Table 1. Choice of fishing activities.

\begin{tabular}{llllll}
\hline FISHING ACTIVITIES & LINE FISHING & DIVING & GILL NETTING & STATIONARY NETTING & TOTAL \\
\hline No. of households & 11 & 4 & 4 & 2 & 21 \\
\hline
\end{tabular}

Source: Table by the author.

Eleven households engaged in line-fishing for tuna, bonito, dolphinfish, grouper, snapper, etc., with outboard motorboats (generally between 20 and $30 \mathrm{hp}$ ) costing about 3,000 pa'anga (over US\$1,500) each (Figure 2). Usually, remittances from emigrated household members or their own earnings from overseas labour were spent for purchasing motorboats and fishing gear. Although the catches were mainly used for their own consumption or distributed to related households, if catches were extremely good, they were sometimes sold at the market in Pangai at three pa'anga per $\mathrm{kg}$, irrespective of the fish species.

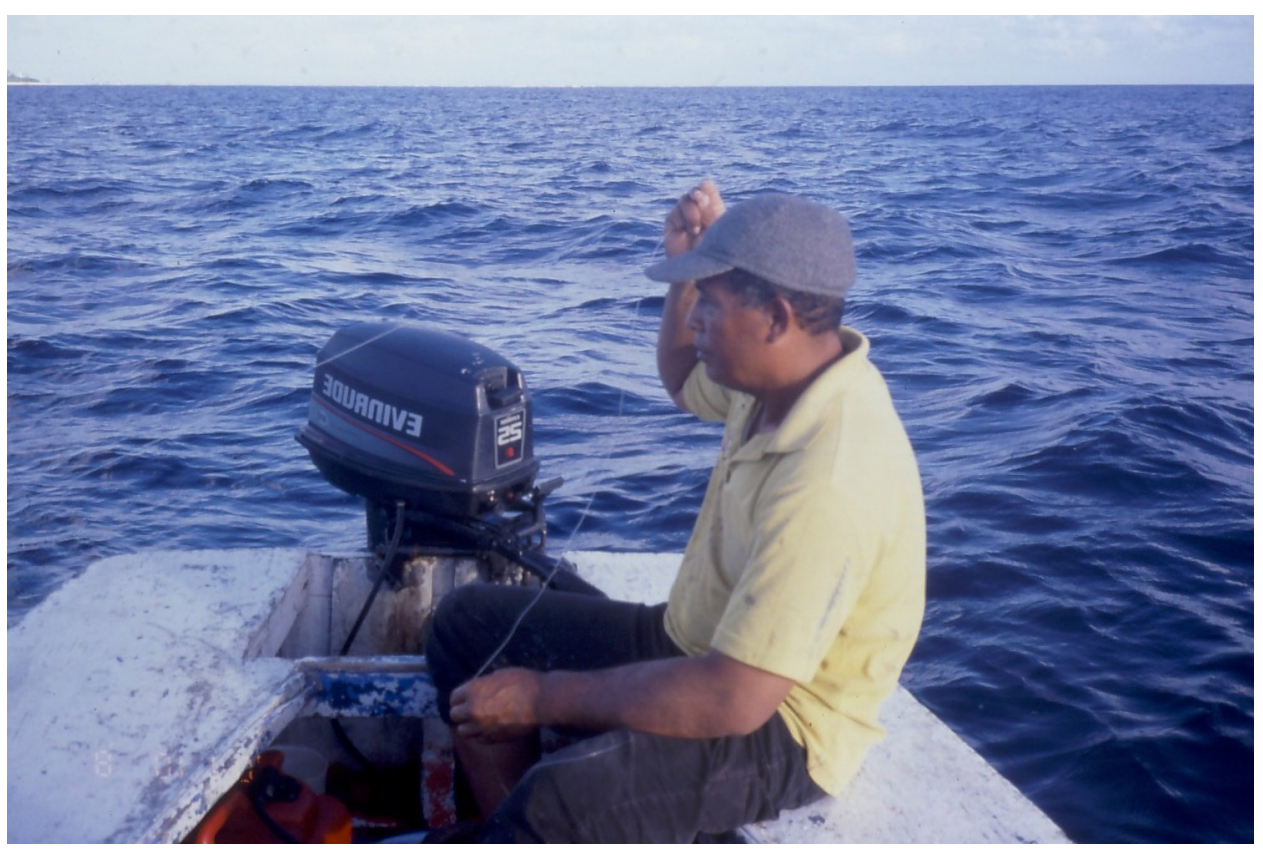

Figure 2. Line fishing.

Source: Photo by the author.

Four households engaged in diving and harpooning for lobster, parrot fish, etc (Figure 3). They did not need to used motorboats and did not invest in expensive fishing gear. Although this lowcost activity could bring good catches, villagers were reluctant to do it for fear of sharks. While the catches were also for a household's own consumption and distribution, they could sell lobster at 10 pa'anga per $\mathrm{kg}$ at the market in Pangai.

Only one household had an encircling gill net (Figure 4). When they used this fishing method, they asked other villagers to help. Usually three to four men worked together to encircle the net and chase the fish schools. The cost of the net was quite high (about 500 pa'anga), and, as of 2001, the catches were sold to other villagers on the beach. The stationary net was also a highcost activity (over 1,000 pa'anga for an initial investment), which needed an iron fence and an impounding net (Figure 5). Two households jointly constructed one stationary net in 2001, after which their catches were also sold to the other villagers on the beach. 


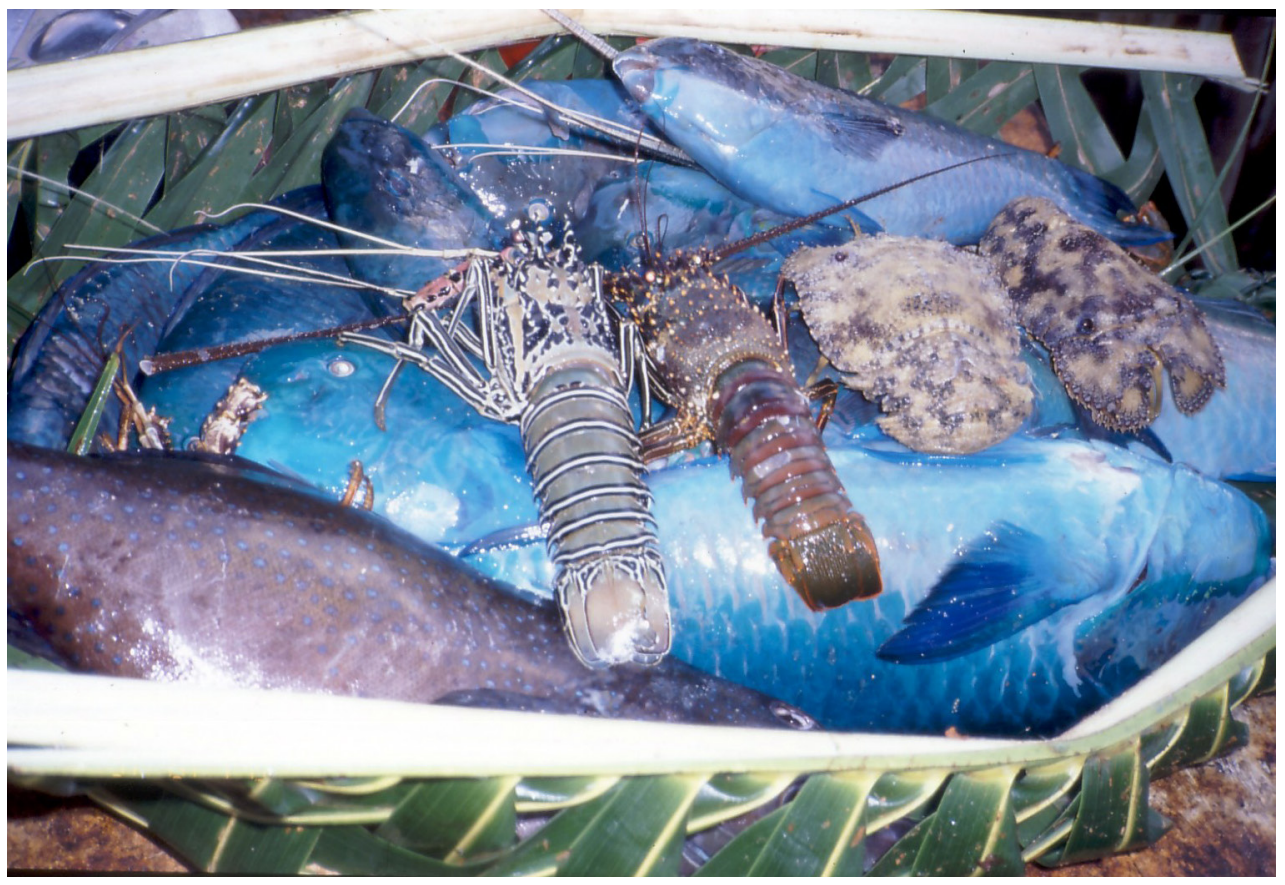

Figure 3. Catches of diving and harpooning.

Source: Photo by the author.

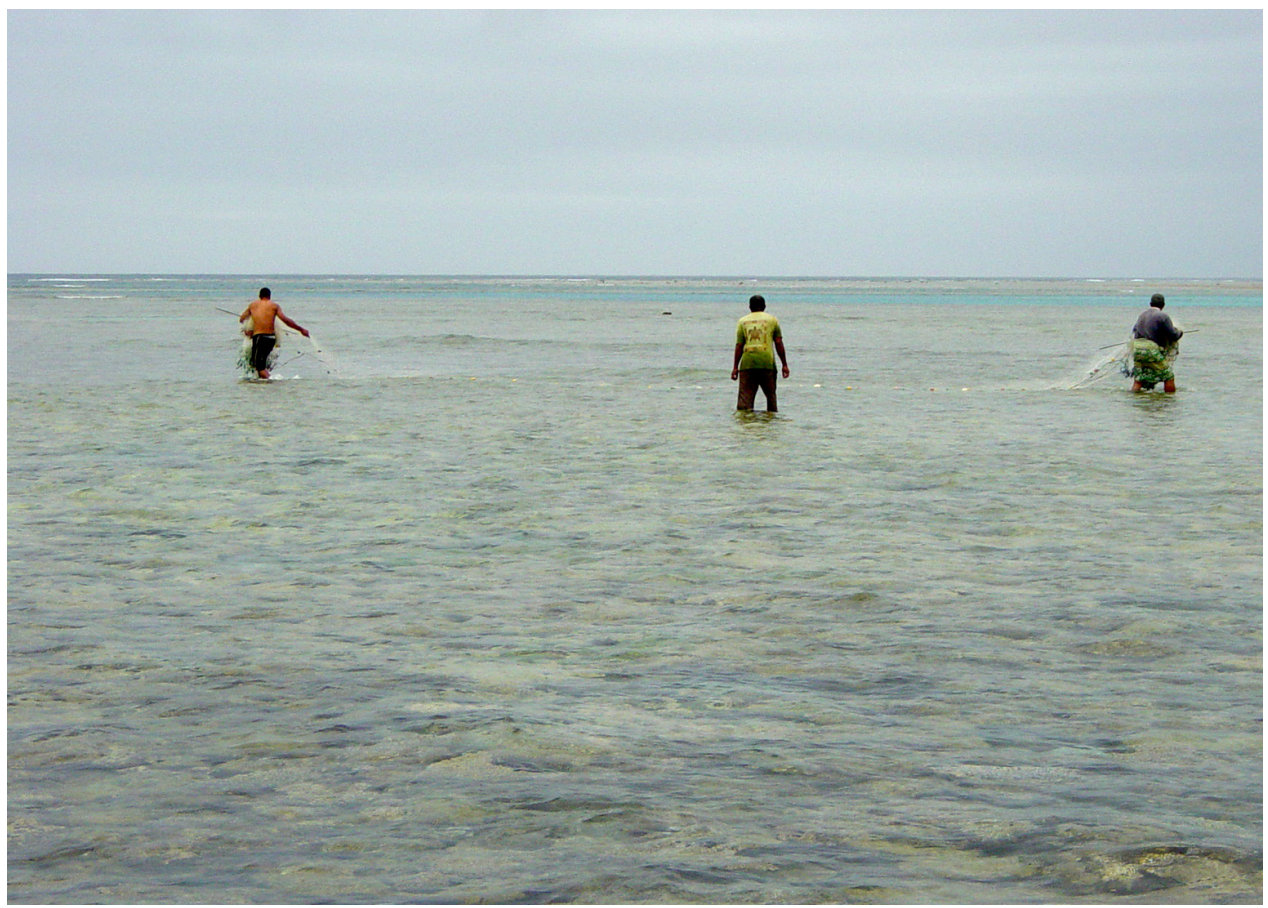

Figure 4. Encircling gill net.

Source: Photo by the author. 


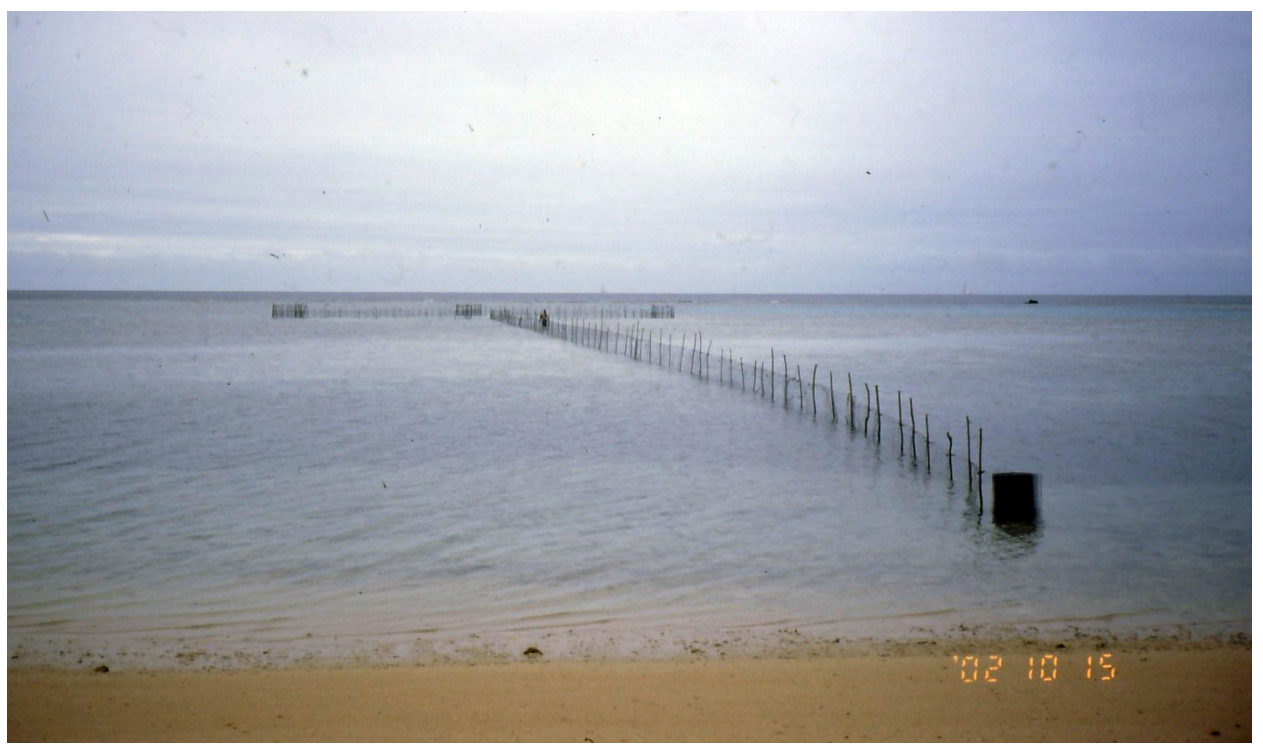

Figure 5. Stationary net.

Source: Photo by the author.

\section{Choice and Productivity of Fishing Activities}

Opportunities to earn money for purchasing fishing gear were very scarce in Ha'ano Village. Villagers usually depended on remittances from emigrated household members for their cash income (Evans 2001). This situation limited the choice of fishing activities. The most expensive investment was buying outboard motorboats, which numbered eight during our research period. Motorboats are important not only for fishing but also for transport to other islands (Figure 6), especially to Pangai to take children to school and purchase living necessities.

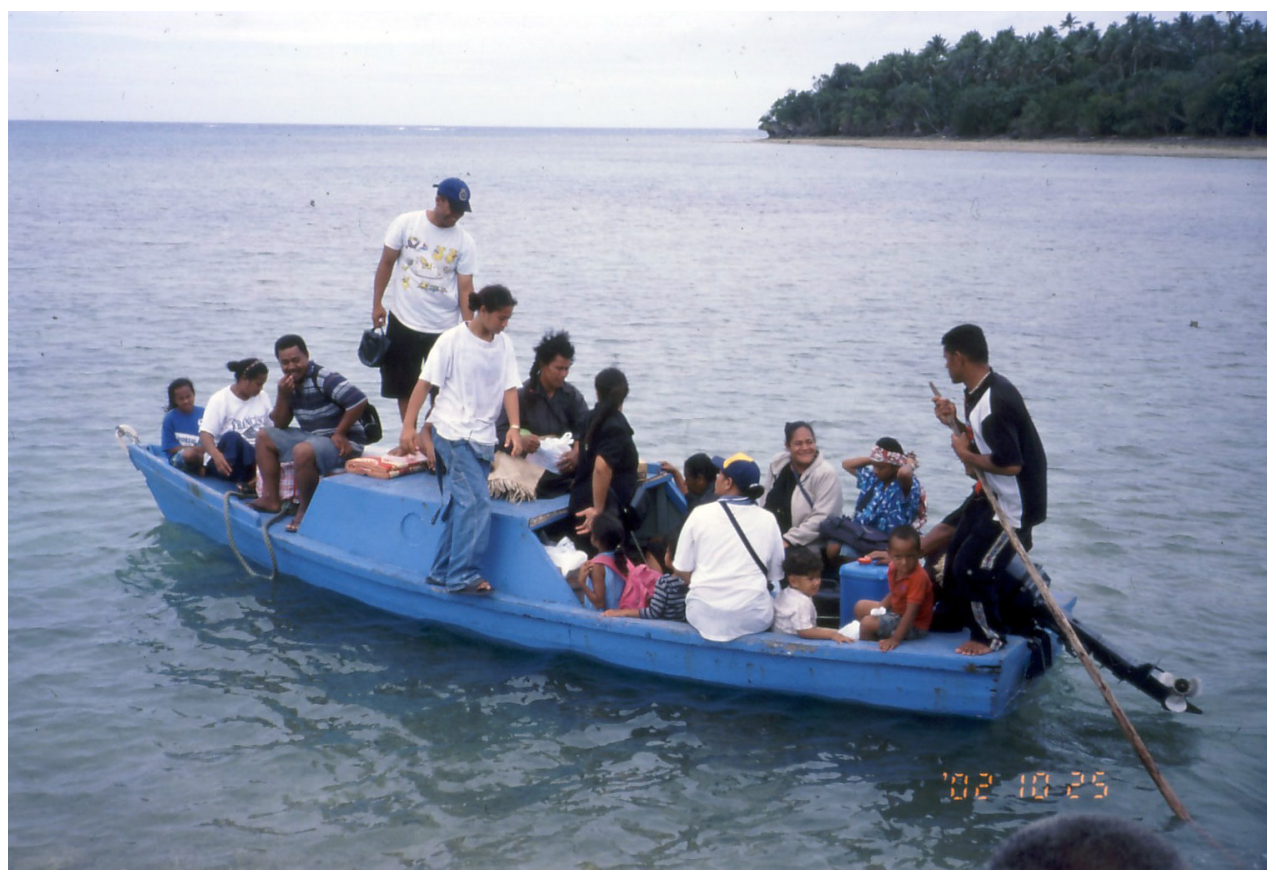

Figure 6. Transporting to other islands by motorboat.

Source: Photo by the author. 
As shown in Table 2, average catches from the four fishing activities above were not so varied (from $14.36 \mathrm{~kg}$ for daytime line-fishing to $21.65 \mathrm{~kg}$ for an encircling gill net); however, the catch variation for line-fishing far surpassed the others. While eleven out of thirty-four line-fishing attempts were in vain, about $76 \%$ of the total catch during daytime $(131.4 \mathrm{~kg})$ and $25 \%$ of nighttime catches $(101.8 \mathrm{~kg})$ were acquired in one attempt. Although diving and harpooning was a steady activity from a cost-benefit standpoint, villagers could sell lobster at the market in Pangai, which was very difficult because they had to keep their catches fresh without a refrigerator. While the catches of encircling nets and stationary nets were not as good during our research period, villagers told us that they could catch hundreds of kilograms of fish when a large school migrated.

Table 2. Productivity of fishing activities.

\begin{tabular}{llllll}
\hline \multirow{2}{*}{ FISHING ACTIVITIES } & LINE FISHING & LINE FISHING & DIVING & NETTING & NETTING \\
\cline { 2 - 6 } & (day time) & (night time) & (harpoon) & gill net & stationary net \\
\hline No. of sample & $\mathbf{1 2}$ & $\mathbf{2 2}$ & $\mathbf{3}$ & $\mathbf{2}$ & $\mathbf{5}$ \\
Main target & bonito, tuna, grouper & tuna, dolphin fish, snapper & lobster, parrot fish & yellow mackerel & yellow mackerel \\
Total catch (kg) & 172.29 & 397.30 & 46.10 & 43.30 & 82.80 \\
Max. catch $(\mathbf{k g})$ & 131.40 & 101.80 & 26.00 & 29.30 & 40.00 \\
Min. catch $(\mathbf{k g})$ & 0.00 & 0.00 & 7.70 & 14.00 & 3.00 \\
Aver. Catch $(\mathbf{k g})$ & 14.36 & 18.06 & 15.37 & 21.65 & 16.56 \\
\hline
\end{tabular}

Source: Table by the author.

\section{Marine Resource Use in Transition}

The number of fishing activities was extremely scarce in comparison to those reported by Vaea and Straatmans (1954), who identified over 40 kinds of fishing activities in Tonga during the first half of the $20^{\text {th }}$ century, and compared to Kirch and Dye (1979), who recorded 37 kinds of fishing activities in the northernmost island of Tonga, Niuatoputapu, in 1976.

The decrease in the variety of fishing activities might be caused by modernisation. The villagers were fond of new activities with modernised fishing gear, which improved fishing efficiency and allowed intensive resource use. As a result, fishermen were prone to concentrate on a few of the most productive activities.

The most popular fishing activity in Ha'ano Village was line-fishing with a motorised boat, which requires a considerable amount of money to buy fuel. Furthermore, as catches were mainly used for household consumption or distribution, villagers rarely got cash from this activity; however, from their viewpoint, food acquisition activities were not for earning cash, but for subsistence, which was a fundamental activity for survival. Earning money from selling fish was simply a byproduct of catch sizes that exceeded their expectations.

Remittances from emigrated family members, however, made it possible (Evans 1999). While farmers on Tongapapu, Tonga's main island, have often sold their harvests to earn cash at the various markets in the islands (Stevens 1999), there were few or no opportunities for the villagers on Ha'ano Island to earn cash.

However, this situation is changing. As mentioned above, two households began to sell the catches from their encircling nets and stationary nets within the village in 2001. Both households' husbands were emigrants who had returned from New Zealand. They sold their catches, not in Pangai, but on the beach just after fishing. Although other villagers initially felt odd about this commercial—rather than reciprocal—exchange, they gradually accepted it. Subsequently, when 
these households engaged in these two fishing activities, they found other villagers would come to the beach to buy fish. Although these two households owned outboard motorboats, they seldom went line-fishing, instead choosing the activities that would earn them a steady income.

It was difficult for the villagers to obtain fish on a daily basis, to some extent because the catches of the major fishing activity — namely, line-fishing_in Ha'ano Village fluctuated. As a result, catches using encircling nets and stationary nets were much in demand.

Circulation of money within the village might cause changes in the socio-economic system. On Mangaia Island, where the sale and brokerage of fish was undeveloped, selling fish assisted the flow of money from those who had enough to spare to those who needed it (Takekawa 1997). In Ha'ano Village, however, it may cause the transformation from a reciprocal economy to one of commercialisation, in which those who have more capital may get more money by investing in modernised fishing gear and a sufficient number of motorboats.

The impacts of commercialisation in Ha'ano Village, however, have been limited in comparison to Southeast Asian regions. For example, in Visaya, Philippines (Torikai 1990) and Saba, Malaysia (Ono 2007), subsistence fishing had shifted to commercial fishing due to the adoption of modernised fishing gear. Along with population growth, the demand for sizeable catches has increased in these regions. As some wealthy fishermen have invested more capital, disparities in income have tended to increase, and the structures of fishing economies have changed drastically. In Ha'ano, however, the changes in the fishing economy have been limited thus far because of a population decrease and isolation from larger consumer markets. The cash circulating within the village is still primarily from the remittances of emigrated family members and, as such, is quite limited. It might be an early sign of the changes caused by economic globalisation. As long as the circulation of the catches is locally restricted, the possibilities of marine resource decline might not be so high.

\section{Conclusion}

While marine resources are still important to the islanders of Oceania even in the face of economical globalisation, the role of those resources has changed. The system of resource utilisation and distribution of catches has shifted from one of reciprocity to one of Western commercialisation.

As discussed above, the Ha'ano villagers rarely sold their catches in the market of Pangai. One of the major reasons for this was that they did not have electric freezers in their village. Because of this, local marine resources and money primarily circulated within the village. The influence of economic globalisation has been very limited in $\mathrm{Ha}$ 'ano Village thus far. Under these conditions, therefore, they hardly overused marine resources simply because demand for those resources is localised and small.

However, with the financial aid of New Zealand, the Tongan government began to offer nighttime electric power to Ha'ano Village in 2003. As electric power would be in ample supply in the near future, the opportunity for using freezers to sell their catches at the market in Pangai would increase. As a result, they might utilise marine resources more intensively in order to earn money to meet their needs and spend on the necessities of modernised life. This, in turn, might result in the circulation of resources and money beyond the village or island and lead to the overuse of their marine resources. We should, therefore, pay attention to the dynamic between intra- and inter-resource management. 


\section{References}

Bellwood, P. 1978. The Polynesians: Prehistory of an Island People. London: Thomes and Hudson.

Evans, M. 1999. Is Tonga's MIRAB economy sustainable? A view from the village and a view without it. Pacific Studies 22:137-166.

Evans, M. 2001. Persistence of the gift. Ontario: Wilfrid Laurier University Press.

Lieber, M.D. 1994. More than a Living: Fishing and Social Order on a Polynesian Atoll. Boulder: Westview Press.

Kirch, P.V. and T.S. Dye. 1979. Ethno-archaeology and the development of Polynesian fishing strategies. Journal of the Polynesian Society 88:53-76.

Oliver, D.L. 1989. Oceania: The Native Cultures of Australia and the Pacific Islands. Honolulu: University of Hawaii Press.

Ono, R. 2007. "Tradition" and "Modernity" in Fishing among the Sama, Eastern Coast of Borneo, Malaysia. Bulletin of the National Museum of Ethnology 31(4):497-579. (in Japanese).

Reinman, F.M. 1967. Fishing: An aspect of Oceanic Economy - An Archaeological Approach. Fieldiana Anthropology 56:95-208.

Stevens, C.J. 1999. Taking over what belongs to God: The historical ecology of Tonga since European contact. Pacific Studies 22:189-219.

Takekawa, D. 1997. Fishing activity as a minor subsistence in Mangaia, Cook Islands: Between subsistence activity and monetary economy. Bulletin for the $50^{\text {th }}$ Anniversary of Kita-Kyusyu University: 341-359. (in Japanese).

Torikai, Y. 1990. Economic Structure of Fishing Villages in the Philippines. Southeast Asian Studies 27(4):406-26. (in Japanese).

Vaea, H. and W. Straatmans. 1954. Preliminary report on a fisheries survey in Tonga. Journal of the Polynesian Society 63:199-215. 